\title{
Age and Individual Productivity: A Literature Survey
}

\author{
Vegard Skirbekk
}

\begin{abstract}
This article surveys supervisors' ratings, analyses of piece-rates and employer-employee datasets as well as other approaches used to estimate how individual productivity varies with age. The causes of productivity variations over the life cycle are addressed with an emphasis on how cognitive abilities affect labour market performance. Earnings tend to increase until relative late in the working life, while most evidence suggests that individuals' job performance tends to increase in the first few years of one's entry into the labour market, before it stabilises and often decreases towards the end of one's career. Productivity reductions at older ages are particularly strong when problem solving, learning and speed are important, while older individuals maintain a relatively high productivity level in work tasks where experience and verbal abilities matter more.
\end{abstract}

\section{Introduction}

Understanding age-productivity profiles is important for several areas of economic research. Given that older individuals are less productive, an ageing workforce can reduce economic growth and decrease fiscal sustainability. If senior workers' wages exceed their productivity levels, older workers represent losses for the companies. Further, successful attempts to increase the retirement age may demand the removal of seniority-based wage systems.

The current article focuses on age differences in individual productivity and their causes. Figure 1 outlines how physical abilities, mental abilities, education and job experience form an individual's productivity potential. Combined with the company's characteristics, these factors determine individual job performance. The weight of the different causal factors in determining individual productivity is steadily changing, where mental abilities and education have long been growing in

1 Contact Details: Vegard Skirbekk, International Institute for Applied Systems Analysis, A-2361 Laxenburg, Austria. E-Mail: skirbekk@iiasa.ac.at. The support of the International Institute for Applied Systems Analysis (IIASA), the Max Planck Institute for Demographic Research and the Norwegian Research Council is gratefully acknowledged. Vegard Skirbekk values the help of David Horlacher, Landis McKellar, Heiner Maier and Alexia Prskawetz as well as comments from Wenke Apt, Sara Grainger, Karsten Hank, Torbjørn Hægeland, Puja Jawahar, Marilyn Brandl, James Raymer, Dorothea Rieck, Pertti Saariluoma and Ingrid Teply. 
importance, while physical abilities have become less important. Changing requirements on the workplace may imply that the ability to absorb new information is becoming increasingly important compared to the length of work experience.

Studies on how job performance differs by age come from several disciplines; including social psychology, medical science and labour economics. The type of research angle used to address this question varies widely, and often according to the researchers' discipline. For instance psychologists tend to use manager's performance ratings, while matched employer-employee datasets have primarily been analysed by economists.

In general, there does not exist any definite way of estimating how productivity varies by age which does not entail a large degree of uncertainty or where the findings are universally valid. Many studies rely on strong assumptions that are likely to bias the estimates, while other investigations only consider a narrow set of jobs and may not be valid for other occupations. In this study, we present a range of different approaches to this problem and also focus on the causes of productivity variations, such as age-differences in job-related cognitive abilities. A broad presentation of the factors that influence age-differences in productivity can provide new insight into the extent and cause of age-related variation in job performance.

This paper is organised as follows: research on age variation in mental abilities is presented in Section 2, the role of experience and learning is discussed in Section 3, while Section 4 debates how mental abilities relate to productivity. Section 5 reviews the evidence on productivity variation between the age groups, Section 6 presents data on age-earnings profiles, Section 7 discusses the rationale of systems where earnings peak at a later age than what productivity does and Section 8 concludes.

\section{Age, Cognitive Abilities and Interrelations with Training}

A large body of evidence supports the notion that cognitive abilities ${ }^{2}$ decline from some stage in adulthood. Verhaegen and Salthouse (1997) present a meta-analysis of 91 studies that describe how mental abilities develop over the life span. These studies show that important cognitive abilities, such as reasoning, speed and episodic memory, decline significantly by the age of 50 . An example of a study on age-differences in abilities is the General Aptitude Test Battery, cross-sectional data collected by the US Department of Labor from 1970 to 1984. The ability levels of employed white men and women up to the age of 65 are shown in Figure 2. The Figure suggests substantial declines in the functional level of most abilities after maximum values are reached in the 20s and early 30s (Avolio and Waldman 1994).

2 "Cognitive" or "mental abilities" refer to broad aspects of intellectual functioning. These include reasoning, spatial orientation, numerical capabilities, verbal abilities and problem solving. The most commonly used measurement of cognitive abilities is the IQ score. 
That mental abilities tend to decline in adulthood is a universal phenomenon. Age-induced changes of mental ability levels are similar for both men and women, and the same patterns are found across different countries (Maitland et al. 2000, Park et al. 1999). Furthermore, individuals with high ability levels are subject to the same changes in cognitive functioning as those with low ability levels (Deary et al. 2000). Age-related reductions in memory and learning capabilities have been documented also among many non-human species, ranging from fruit flies to primates, (Bunk 2000, Minois and Bourg 1997).

In spite of the seemingly unavoidable age-related reductions in cognitive abilities, targeted training programmes may provide a way of halting the decline. Schaie and Willis (1986a, 1986b) conclude that such programmes can stabilise, or even reverse, age-related declines in inductive reasoning and spatial orientation among many individuals. Similar evidence is presented by Ball et al. (2002) who find that persons who exercise the use of abilities such as speed, reasoning and memory enhance the functional level of these abilities.

Certain cognitive abilities tend to be relatively robust against age-induced declines (Schaie 1994). A division can be drawn between crystallised abilities, which remain at a high functional level until a late age in life and fluid abilities, mental abilities that are strongly reduced over the life span (Horn and Cattell 1966, 1967). Crystallised abilities are accumulated knowledge, such as verbal meaning and vocabulary size. The second group, fluid abilities, concern the performance and speed of solving tasks related to new material, and include perceptual speed and reasoning abilities.

Schwartzman et al. (1987) find that verbal skills (crystallised abilities) remain virtually unchanged, while reasoning and speed (fluid abilities) decline with age, based on psychometric test results of men in different age groups. In a test-retest study of twins, Blum et al. (1970) provide similar findings: Vocabulary size is observed to remain constant from young to old ages, despite a general reduction in other cognitive abilities.

Cross-sectional analyses, which describe the current population's abilities, typically find a younger ability peak than longitudinal data, which follow a panel of individuals' ability levels over their life cycle. This is for example the case in the "Seattle Longitudinal Study" (Schaie 1996), where both longitudinal and a cross-sectional ability differences by age are collected. Findings from the longitudinal dataset from the study indicate that word fluency does not decline before the age of 53, while according to recent cross-sectional data from the same study, this ability starts to decline already after the age of 25.

Both longitudinal and cross-sectional approaches for measuring age-ability differences are subject to problems. The weaknesses of longitudinal studies could suggest that the age-ability estimates are biased upwards (Willis and Baltes 1980): Large attrition, where those who are lost are likely to be negatively selected, means that the 
sample that remains in later waves is positively selected. ${ }^{3}$ Another source of error stems from test practice, meaning that when individuals who participate in the survey in subsequent waves perform better simply because they have taken similar tests beore (in earlier waves of the study) and are therefore more trained at being in a test sit uation and used to the type of questions that are being asked.

On the other hand, analyses of data based on a cross-sectional approach could lead to a downward bias in the age-ability curves, since average ability levels have increased over time for more recent cohorts (Dickens and Flynn 2001, Willis and Schaie 1998). Individuals from younger cohorts are likely to be more motivated at taking ability tests, as such tests are increasingly being used in job candidate selection processes (Jenkins 2001). Furthermore, younger cohorts have more education, which is also likely to increase their test performance (Flynn 1987).

\section{Experience and Learning}

The decreased cognitive abilities of older workers can lead to lower productivity, unless their longer experience and higher levels of job knowledge can outweigh the decline in mental abilities. Warr (1994) suggests a categorisation of professions according to whether age boosts or reduces performance. Here, jobs are distinguished according to whether reduced cognitive performance and/or long experience will affect job performance. Salthouse (1984) uses typists as an example of a profession where experience alleviates the impact of cognitive reductions. He finds that older typists use more efficient work strategies and therefore work as effectively as their younger counterparts despite their reduced speed.

The productivity profile may change over time given structural changes in the labour market. Accelerating technological progress can increase the importance of being able to learn and to adjust to new ways of working, while a long work experience become less important. This is particularly problematic for older employees, due to age-related declines in processing speed and learning capacities (Baltes and Lindenberger 1997, Hoyer and Lincourt 1998).

Fewer training opportunities are offered to older workers than to younger ones, which could lower their human capital and productivity level. One factor influencing the companies' decision of whether to invest in their workers' human capital is the expected number of years left in the working life before retirement. Since senior workers have a shorter duration to pay back firms' investments in human capital and productivity, they are offered fewer opportunities to participate in training programmes. However, if the retirement age increases, the company's expected pay-off from human capital investments would be higher, which could increase the

3 In one of the most influential longitudinal studies of how cognitive abilities develop over the life cycle, the Seattle Longitudinal Study, more than half of the initial sample was lost by the time of the third wave (Schaie 1994). 
amount of training offered to older individuals and improve their human capital level.

The elderly learn at a slower pace than younger individuals especially if what they learn is qualitatively different from what they already have mastered. Rybash et al. (1986) argue that as people grow older, they undergo an encapsulation of job know-how, implying that the individuals' skills are attached to certain work domains and increasingly less transferable. In some occupations, the cognitive abilities that remain stable are the ones most closely correlated with job success. Senior employees can remain highly productive within a field that they know well and where long experience is beneficial. Tacit knowledge is procedural knowledge used to solve everyday problems, which tends not to decrease at older ages. The age-robustness of this ability could explain why many older managers perform as good as younger ones (ColoniaWillner 1998). However, when performing unfamiliar work, workers have to rely on the ability to learn and to adjust, exactly those skills that decline most with age. Senior individuals are less able than young individuals to reorient themselves to new task requirements and to solve novel problems (Smith 1996) and age-induced productivity reductions may increase with the complexity of the work task (Myerson et al. 1990).

Job experience improves productivity for several years, but there does come a point at which further experience no longer has any effect. Ilmakunnas et al. (1999) assess a broad sample of Finnish manufacturing employees, and find that job duration improves job performance for only up to a length of 3.8 years. Ericsson and Lehmann (1996), however, argue that it takes roughly 10 years to achieve expert competence in games and situations where strategic and analytic competence is important, such as in chess. In summary, on-the-job-training increases productivity up until a point where additional experience no longer improves productivity.

\section{Cognitive Abilities, Productivity and Wages}

Age-related variations in mental abilities are likely to affect productivity levels because they are one of the most important determinants of education and work success (Barrett and Depinet 1991). Schmidt and Hunter (1998) investigate how different individual characteristics, such as education, work experience and general mental abilities, relate to job performance. They find that mental ability tests predict a person's job performance better than any other observable characteristic.

Currie and Thomas (1999) and Tyler et al. (2000) find that mental ability levels measured at young ages determine adult income levels, adjusting for socio-economic characteristics. Currie and Thomas examine scores from a general mental ability test at the age of 7, while Tyler et al. analyse the test results of high school drop-outs in math, writing, reading, science and social studies. A range of other studies give further weight to the notion that mental ability levels determine wage levels, including Bishop (1991), Boissiere et al. (1985), Dolton and Vignoles (2000), Grogger and Eide (1993) and Murnane et al. (2000). 
Longitudinal studies find an increasingly strong correlation between test scores and wages over time. Murnane et al. (1995) study the relationship between mathematics test performance at the end of high school and hourly wages in the U.S and maintain that the relation is becoming stronger over time. Also Juhn et al. (1993) find empirical support for the increasing payoff to ability levels within narrowly defined school and occupational groups. Further, the increased demand for cognitive skills in the last few decades applies for the labour market as a whole, at least in the US (Autor et al. 2003).

\section{Measuring Productivity of individuals at Different Ages}

This section surveys the main approaches used to measure job performance differences by age. The approaches discussed include supervisors' ratings, piece-rate samples, employer-employee matched data sets as well as age-specific employment and earnings structures.

Studies based on supervisors' ratings typically do not find any clear systematic relationship between the employee's age and his or her productivity. A meta-analysis by Waldman and Avolio (1986) based on 18 supervisor assessment samples finds a slightly negative impact of age on job performance and argues that only a small part of the productivity variation could be attributed to age. McEvoy and Cascio (1989) review 96 studies on the impact of the employee's age on supervisors' assessment and sales records and find no clear effect of age on productivity. Remery et al. (2003) analyse a survey of 1007 Dutch business leaders and personnel managers regarding their workers' age and their productivity. They find that older individuals are seen as less productive in particular in workplaces with more older employees, which is where knowledge about older individuals' work capacities is likely to be highest. Medoff and Abraham $(1980,1981)$ find that the length of job tenure is either unrelated or negatively associated to performance evaluations of white-collar American workers.

A general disadvantage with the use of supervisors' ratings to rank individuals by age and productivity is that managers may wish to reward older employees for their loyalty and past achievements. This can inflate the evaluations of senior employees and thus bias the results (Salthouse and Maurer 1996). Dalton and Thompson (1971) investigate performance evaluations not only from supervisors, but also from other employees, in six large companies undergoing rapid technological change. The ratings from the engineers and their managers suggest that employees in their 30s put in the most effort and perform the most sophisticated technical work, and that productivity falls as the engineers move into their 40s and beyond.

A second approach to measuring the impact of age on job performance is based on piece-rates, measuring the quantity and quality of a worker's output. Studies based on this approach tend to find that older employees have lower productivity levels. Mark (1957) and Kutscher and Walker (1960) provide some evidence that mail sorters and office workers kept productivity quite stable at higher ages, while factory 
workers' productivity fell after the age of 55. A study of a broad range of industries from the U.S. Department of Labor (1957) finds that job performance increases until the age of 35 to be on a steady decline thereafter. At the end of the career, productivity declines by $14 \%$ in the men's footwear industry, and $17 \%$ in the household furniture industry.

These task-quality/speed tests are potentially more objective as they rely less on subjective managerial assessment, but may suffer from the fact that the workers are selected in terms of age groups and occupational types (Rubin and Perloff 1993). Further, the time-limit common in such studies may bias results. For example older employees may maintain a higher work speed in the short period they are studied than what they would be able to in a normal job situation (Salthouse and Maurer 1996).

The productivity of individuals doing "creative" jobs, such as researchers, authors and artists can also be measured by the quantity as well as the quality of their output. Stephan and Levin (1988) study researchers in the fields of Physics, Geology, Physiology and Biochemistry. The number of publications and the standard of the journals they appear in are found to be negatively associated with the researchers' age. Similar evidence is found in the field of economics, where Oster and Hamermesh (1998) conclude that older economists publish less than younger ones in leading journals, and that the rate of decline is the same among top researchers as among others. Further evidence suggesting that there is a negative association between either age or tenure and scientific output is found in Bayer (1977) and Bratsberg et al. (2003).

Miller (1999) describes how the output of artists varies across their life span. He analyses the number of paintings, albums and books produced by 739 painters, 719 musicians and 229 writers and find that the peak ages for creative output seem to be in the 30s and 40s, the only exception being female authors who write most in their 50 s.

A third way of measuring productivity by age is based on the analysis of employer-employee matched data-sets ${ }^{4}$, where individual productivity is measured as the workers' marginal impact on the company's value-added. These datasets gives information both on wages and productivity estimates, which allows a comparison whether productivity estimates differ from individual wages. These studies are likely to be less subjective than those based on supervisors' ratings, and there are fewer sample selection problems than studies based on piece-rates. However, the main challenge in this approach is to isolate the effect of employees' age from other influences on the company's value-added, which leads to strong identifying assumptions.

An overview over how employer-employee studies relate to age is presented in Table 1. For most of the employer-employee studies, an inverted U-shaped work performance profile is found (Andersson et al. 2002, Crépon et al. 2002, Ilmakunnas et

4 A survey of analyses based on matched employer-employee data can be found in Abowd and Kramarz (1999). 
al. 1999, Haltiwanger et al. 1999, Hægeland and Klette 1999). Here, individuals in their 30s and 40s have the highest productivity levels. Employees above the age of 50 are found to have a lower productivity than younger individuals, in spite of their higher wage levels.

Exceptions to findings suggesting that productivity decreases with age include a study of American companies by Hellerstein et al. (1999), who estimate that productivity increase with age, where those above 55 contribute the most to output levels. However, the authors find that the peak productivity shifts to 35-54-year-olds workers when they use the companies' value-added instead of output levels as an indicator of productivity. Moreover, an earlier analysis based on the same dataset (Hellerstein et al. 1996) concluded that workers' productivity decreases with age also in the case when the companies' output is used as an indicator of productivity.

A problem with the fact that most studies on age-productivity differences are based on cross-sectional evidence is that seniority leads to occupational shifts. Good workers get promoted, while inefficient workers lose their jobs or are demoted. This can cause estimation bias, since selectivity increases with age. Employer-employee datasets also have the problem that a company's success can increase the number of new employees and lead to a younger age structure, which could lead to wrong estimates since a young age structure could be the consequence rather than the cause of a company's success. Using a lagged measure of the company's age composition to estimate current productivity can overcome this problem, as worker influx or outflow to the company will have less of an impact on the worker's productivity. Andersson et al. (2002) use such lagged measures of the worker's age in their analysis of employer-employee data, and their findings support the idea that older workers tend to be less productive than younger ones. However, they also find that tertiary non-technical workers tend to positively affect productivity until a later age.

Age-earnings profiles can provide information on productivity profiles in settings where wages reflect current productivity. One example is a study by Lazear and Moore (1984) who examine the difference between earnings profiles of the self-employed and salary workers. They find that the self-employed tend to have little wage variation over the life cycle, while salary workers have increasing wages throughout their career. This suggests that productivity remains stable over the life cycle. A study by Boot (1995), describe age-earnings profiles for British workers in the first half of the $19^{\text {th }}$ century, when there were few regulations in the labour market. For the physically demanding work analysed here, men reached their peak earnings in their early 30 s, and wages decreased substantially from around 40 years of age. In a similar study, Johnson (2003) looks at British manual workers' earnings from the 1830s to the 1930s, and find a stable age-earnings pattern where wages reach their peak in the mid-30s and remain stable or decline slightly thereafter.

Changes in the labour market attachment could also provide information on the labour market attachments over time. If older workers cope less well with changes on the workplace, then rapid changes should affect them worse than younger age groups. Bartel and Sicherman (1993) put forward evidence that the risk of job loss is 
in fact greater among older workers when the rate of technological change is highest. This finding is also supported in studies based on inter-industry and international data (Ahituv and Zeira 2000, Clark et al. 1999).

Analyses of the relation between changes to the age structure of the population and aggregate measures of performance, such as technical progress or economic growth can also provide insight about workers' productivity. Nishimura et al. (2002) investigate the impact of age structure on technical progress and added-value growth in Japanese industries for the years 1980-1998. They estimate the relation between technological progress and the staff's age structure and find that the relation between the share of educated workers older than 40 years and technological progress is positive in the 1980s, but turned negative in the 1990s. This may be due to a higher rate of technological change in the 1990s which shifted the productivity peak towards younger ages.

Lindh and Malmberg (1999) and Malmberg and Lindh (2002) find that the initial size of the share of the 50-64 age group is positively correlated to economic growth in each subsequent 5 -year period, by studying age structure and economic growth in the OECD for the period 1850-1990. No clear effect is made out for younger age groups. Although the causal mechanism of this correlation is not identified, these investigations suggest that productivity peaks late in the working life. However, there are several other plausible reasons why the proportion of 50-64 year olds is positively associated with economic growth. One possibility would be that there is an unobserved factor which affects the level of economic growth as well as demographic indicators such as life expectancy, which influences age structure. Hence, the association between age structure and growth is not necessarily due to that older workers are more productive.

\section{Age-Earnings Profiles}

A wage analysis provided by the OECD shows that for 17 out of the 19 countries observed, ${ }^{5}$ gross wages peak for the $45-54$ age group (OECD 1998). The age-earnings profile is characterised by a relatively steep increase in wage levels until the peak is reached followed by a mild reduction in earnings the last years before retirement. The 25-29 age group earns on average 0.72 of what the $45-54$ age group earns, while the 55-64 age group earns 0.91 of what the 44-54 age group does. ${ }^{6}$ Age-related differences in wages increase with the level of education (OECD 1998). For individuals with less than an upper secondary education, the 25-29 age group earned

5 The countries in the study were Australia, Canada, Denmark, Finland, France, Germany, Ireland, Italy, Japan, Mexico, the Netherlands, New Zealand, Norway, Portugal, Sweden, Switzerland and the U.S. For the Czech Republic and the UK, the wages peaked for the 35-44 age group.

6 These percentages represent unweighted averages for the countries in the study. 
0.81 times of what the $45-54$ age group earned, while for those with a university education, those aged 25-29 earned only 0.53 times of what the $45-54$ age group earned.

\section{Age-Earnings and Productivity Profiles}

Based on the evidence presented in previous sections, the apparent late peak in the age-earnings profile contrasts with the earlier peak in productivity level. This suggests that there is a discrepancy between productivity and wages, with wages being lower than productivity levels at young ages, unless productivity estimates are wrong. ${ }^{7}$ Figure 2 shows a stylised situation which assumes that younger workers are underpaid, and older workers overpaid, relative to their productivity. Hence, companies can only profit from employing the young. The implications in the case of population ageing is shown, where the companies' profits decrease as the share of unprofitable older workers increase. Therefore, as the share of older workers increase, the companies' incentive will be either to dismiss them or to lower their wages.

Several theories have emerged to explain the rationality of why age-earnings profiles peak later than the relevant productivity profiles. One important reason is employers' initial uncertainty about new employees' productivity levels (Harris and Holmstrom 1982). Older workers are paid above their marginal productivity, since upwardly sloping wage profiles strengthen the employees' work effort by raising their shirking costs, lower the companies' need to train new workers and decrease the risk of company secrets being leaked to competing companies because of low staff turnover. Further, when older workers receive higher wages as a reward for past productivity, junior workers' loyalty to the company can rise since they will also want to reap the rewards of a bonus for long service. Hutchens (1989) argues that this type of incentive systems, delayed payment contracts, is most frequently used when workers' performance is difficult to observe and measure.

An important reason why it is in the interest of company owners to have a wage peak at a relatively high age is that the average worker used to be rather young, so that until recently, companies have gained from having a delayed payment contract as long as most workers are paid below their marginal productivity. However, as Lazear (1988) contests, population ageing challenges the financing of such systems, by increasing the companies' incentives to either decrease the wages of older individuals' or to lay them off.

Delayed payment contracts may implicitly require that individuals have either life-long contracts with their employees or that any job switches are done between

7 Alternatively, one could argue that wages and productivity levels match at all ages. Age-related earnings profiles indisputably slope upwards, while there is uncertainty about the shape of the age-related productivity curve. One could therefore argue that it is the productivity profile which is incorrectly estimated, and that the true productivity profile is identical to the age-related earnings profile. 
companies with similar wage systems. However, when a worker could choose between working in company A, where the wages peak early in life and company B, where the wages peak late in life, this type of payment system can not be sustained. The profit-maximizing worker could spend his/her younger years in company A with high initial wages, and then switch to firm B with high seniority-wages in the middle of his/her career. Consequently, firm B will lose young workers who otherwise would bear the costs of seniority wages. Having age-earnings curves with different slopes can therefore become more difficult over time, as the frequency of job shifts increases (Bergmann and Mertens 2002, Burgess and Rees 1996), which suggests that age-earnings profiles of companiess employing the same type of workers would need to harmonise. This can affect the shape of the age-earnings profile, and make it more similar to the age-productivity curve, where wages peak at younger ages.

\section{Conclusion}

Studies that estimate the influence of age on individual productivity is based on different indices, including supervisors' evaluations, piece-rate studies and analyses of employer-employee datasets. Most piece-rate studies, measuring the quantity and quality of the workers' output, and analyses of employer-employee datasets, where a companies' productivity is measured, suggest that productivity follows an inverted U-shaped profile where significant decreases are found after the age of 50. A problem with most estimates of how productivity varies by age is that older individuals who remain in the workforce are positively selected and have a higher productivity than that of those leaving the workforce, which can bias the estimates. Further, although supervisors' evaluations on average show little or no relationship between the assessment score and the age of the employee, subjective opinions may be biased, where for example the management's opinions of older employees may be inflated due to loyalty reasons.

An important cause of these age-related productivity declines is likely to be age-specific reductions in cognitive abilities. Some abilities, such as perceptual speed, show relatively large decrements already from a young age, while others, like verbal abilities, exhibit only small changes throughout the working life. Experience boosts productivity up to a point beyond which, however, additional tenure has little effect. Older individuals learn at a slower pace and have reductions in their memory and reasoning abilities. In particular, senior workers are likely to have difficulties in adjusting to new ways of working.

Older workers may possess characteristics which are important to the companies' success, but difficult to measure. Senior employees may have a wider professional network, give training and guidance, provide tacit knowledge, uphold norms that prevent shirking and opportunistic behaviour, and know better how to deal with problems arising with relatively low frequencies. Such factors are difficult to quan- 
tify, in particular in studies of quantity of output such as studies of piece-rate companies. However, other approaches, such as the analysis of employer-employee datasets, can be in a better position to capture such effects.

Authorities in most ageing economies encourage 'active ageing' policies aiming at increasing labour market participation of older individuals. The productivity loss associated with early retirement indicates that this emphasis is entirely justified. However, active ageing policy programmes should take into account that seniority-based compensation systems could create a disparity between earnings and productivity at senior ages, which might lower the employment opportunities for many older individuals.

\section{References}

Abowd, J. and F. Kramarz. 1999. "The Analysis of Labor Markets Using Matched Employer-Employee Data.”, Ch. 40 in Ashenfelter, Orley and David Card eds. Handbook of Labor Economics, Vol. 3, Elsevier Science, Holland, pp. 2630-2672.

Ahituv, A. and Joseph Z. 2000. "Technical Progress and Early Retirement.", CEPR Discussion Paper, No. 2614 November

Andersson, B., B. Holmlund and T. Lindh. 2002. "Labor Productivity, Age and Education in Swedish Mining and Manufacturing 1985-96", Unpublished Paper, Uppsala, Sweden.

Autor, D. H., F. Levy and R. J. Murnane. 2003. "The Skill Content of Recent Technological Change. An Empirical Exploration.", Quarterly Journal of Economics, Vol. 118, No. 4.

Avolio, B. J. and D. A. Waldman 1994. Variations in Cognitive, Perceptual, and Psychomotor Abilities Across the Working Life Span: Examining the Effects of Race, Sex, Experience, Education, and Occupational Type. Psychology and Aging, Vol. 9, No. 3, pp. 430-442.

Ball, K., D. B. Berch, K. F. Helmers, J. B. Jobe, M. D. Leveck, M. Marsiske, J. N. Morris, G. W. Rebok, D. M. Smith, S. L. Tennstedt, F. W. Unverzagt, S. L. Willis. 2002. 2002. "Effects of Cognitive Training Interventions With Older Adults.", Journal of the American Medical Association, Vol. 288, No. 18 (Nov), pp. 2271-2281.

Baltes, P. B. and U. Lindenberger 1997. "Emergence of a Powerful Connection Between Sensory and Cognitive Functions Across the Adult Life Span. A new Window to the Study of Cognitive Aging?", Psychology and Aging, Vol. 12, No. 1, pp. 12-21.

Barrett, G. V. and R. L. Depinet 1991. "A Reconsideration of Testing for Competence Rather than for Intelligence.", American Psychologist, Vol. 46, No. 10, pp. 1012-1024. 
Bartel, A. P. and N. Sicherman 1993. "Technological Change and Retirement Decisions of Old Workers.", Journal of Labor Economics", Vol. 11, Issue 1 (Jan), pp. 162-183.

Bayer, A. E. and J. E. Dutton 1977. "Career, Age and Research Professional Activities of Academic Scientists.", Journal of Higher Education, Vol. 48, No. 3 (May/Jun), pp. 252-282.

Bergmann, A. and A. Mertens 2002. "Job Stability Trends, Layoffs and Quits-An Empirical Analysis for West Germany.”, Mimeo, Max Planck Institute for Human Development

Bishop, J. H. 1991. "Achievement, Test scores, and Relative wages."in Kosters, Marvin H. ed. 1996. Workers and their wages, Washingtion DC, AEI Press 1991.

Blum, J. E., L. F. Jarvik and E. T. Clark. 1970. "Rate of Change on Selective Tests of Intelligence. A Twenty-Year Longitudinal Study of Aging.", Journal of Gerontology, No. 25, pp. 171-176.

Boissiere, M., J. B. Knight and R. H. Sabot. 1985. "Earnings, Schooling, Ability and Cognitive skills.", American Economic Review, Vol. 75, No. 5, pp. 1016-1030.

Boot, H. M. 1995. "How skilled were Lancashire cotton factory workers in 1833?", Economic History Review, No. 2, pp. 283-303.

Bratsberg, B., J .F. Ragan, Jr., and J. T. Warren. 2003. "Negative Returns to Seniority: New Evidence in Academic Markets.", Industrial and Labor Relations Review, Vol. 56, No. 2 (Jan), pp. 306-323.

Bunk, S. 2000. "Cognition and Aging. A Rare Colony of Old Macaques Gives Clues to Age Impairment", The Scientist, Vol. 14, No. 18 (Sep).

Burgess, S. and H. Rees 1996. "Job Tenure in Britain 1975-92.", The Economic Journal, No. 106 (Mar), pp. 334-344.

Clark, R., E. A. York, and R. Anker. 1999. Economic Development and Labor Force Participation of Older Persons. Population Research and Policy Review, No. 18, pp. 411-432.

Colonia-Willner, R. 1998. "Practical Intelligence at Work: Relationship Between Aging and Cognitive Efficiency Among Managers in a Bank Environment.", Psychology and Aging, Vol. 13, No. 1,pp. 45-57.

Crépon, B., N. Deniau and S. Perez-Duarte. 2002. "Wages, Productivity and Worker Characteristics. a French Perspective.", Mimeo, INSEE.

Currie, J. and D. Thomas 1999. "Early Test Scores, Socioeconomic Status and Future Outcomes.", NBER Working Paper 6943.

Dalton, G. W. and P. H. Thompson 1971. "Accelerating Obsolence of Older Engineers.", Harvard Business Review, Vol. 49, No. 5, pp. 57-67.

Deary, I. J., L. J. Whalley, H. Lemmon, J. R. Crawford and J. M. Starr. 2000. “The Stability of Individual Differences in Mental Ability from Childhood to Old Age. Follow-Up of the 1932 Scottish Mental Survey.", Intelligence, Vol. 28, No. 1, pp. 49-55.

Dickens, W. and J. Flynn 2001. Heritability Estimates Versus Large Environmental Effects: The IQ Paradox Resolved. Psychological Review, 108 (2): 346-369. 
Dolton, P. J. and A. F. Vignoles 2000. "The Pay-Off to Mathematics A-Level.", in C. Tikly and A. Wolf eds. The maths we need now, pp. 52-73.

Ericsson, K. A. and Lehmann A. C. 1996. "Expert and exceptional performance: Evidence of maximal adaption to task constraints.", Annual Review of Psychology, No. 47, pp. 273-305.

Flynn, J. R. 1987. "Massive IQ gains in 14 Nations. What IQ Tests Really Measure."Psychological Bulletin, No. 101, pp. 171-191.

Grogger, J. T. and E. Eide 1993. "Changes in College Skills and the Rise in the College Wage Premium.", Journal of Human Resources, Vol. 30, No. 2 (Spring), pp. 280-310.

Haltivanger, J. C., J. I. Lane and J. R. Spletzer. 1999. "Productivity Differences Across Employers. The Roles of Employer Size, Age and Human Capital.", American Economic Review, Papers and Proceedings 89, No.2 (May), pp. 94-98.

Harris, M. and B. Holstrom. 1982. "A Theory of Wage Dynamics.", Review of Economic Studies, No. 49, pp. 316-33.

Hellerstein, J. K. and D. Neumark. 1995. "Are Earnings Profiles Steeper than Productivity Profiles? Evidence from Israeli Firm-Level Data.", Journal of Human Resources, Vol. XXX, No. 1, pp. 89-112.

Hellerstein, J. K. and David N. and K. R. Troske. 1996. "Wages, Productivity and Worker Characteristics: Evidence From Plant Level Production Function and Wage Equations.", NBER Working Paper Series, No. 5626.

Hellerstein, J. K. and D. Neumark and K. R. Troske. 1996. "Wages, Productivity and Worker Characteristics: Evidence From Plant Level Production Function and Wage Equations.", Journal of Labor Economics, No. 17, pp. 409-446.

Horn, J. L. and R. B. Cattell 1966. "Refinement and Test of the Theory of Fluid and Crystallized Intelligence.", Journal of Educational Psychology, No. 57, pp. 253-270.

Horn, J. L. and Raymond B. Cattell 1967. "Age Differences in Fluid and Crystallized Intelligence.”, Acta Psychologica, No. 26, pp. 107-129.

Hoyer, W. J. and A. E. Lincourt 1998. "Aging and the Development of Learning.", ch. 13 in M. A. Stadler ed. Handbook of implicit learning, Sage Publications, US, pp. 445-470.

Hutchens, R. 1989. “Seniority, Wages and Productivity: A Turbulent Decade.", Journal of Economic Perspectives, Vol. 3, No. 4, pp. 49-64.

Hægeland, T. and T. J. Klette 1999. "Do Higher Wages Reflect Higher Productivity? Education, Gender and Experience Premiums in a Matched Plant-Worker Data Set.", in Haltiwanger, J. L., J. R. Spletzer, J. Theeuwes and K. Troske 1999. The Creation and Analysis of Employer-Employee Matched Data, Elsevier Science, Holland.

Ilmakunnas, P., M. Maliranta and J. Vainiomäki. 1999. "The role of Employer and Employee Characteristics for Plant Productivity.'WP-223, Helsinki School of Economics and Business Administration. 
Jackson, W. A. 1998. Political Economy of Population Ageing, E. Elgar Publishing Limited, United Kingdom.

Jenkins, A. 2001. 'Companies' Use of Psychometric Testing and the Changing Demand for Skills: A Review of the Literature.", Centre for the Economics of Education Working Paper", LSE, United Kingdom.

Johnson, P. 2003. "Age, gender and the wage in Britain", in P. Scholliers and L. Schwarz, eds., Worlds of Wages, New York: Berghahn, pp. 229-49.

Juhn, C., K. M. Murphy, B. Pierce. 1993. "Wage Inequality and the Rise in Returns to Skill.”, Journal of Political Economy, Vol. 101, No. 3, pp. 410-442.

Kutscher, R. E. and J. F. Walker 1960. "Comparative Job Performance of Office Workers by Age."Monthly Labor Review, Vol. 83, No. 1, pp. 39-43.

Lazear, E. P. 1979. "Why is there Mandatory Retirement?", Journal of Political Economy, Vol. 87, No. 6.

Lazear, E. P. 1988. "Adjusting to an Aging Labor Force.", NBER Working Paper, No. 2802.

Lazear, E. P. and Robert L. Moore 1984. "Incentives, Productivity, and Labor Contracts.", The Quarterly Journal of Economics. Vol. 99, Issue 2, pp. 275-296.

Lindh, T. and B. Malmberg (1999): "Age Structure and Growth in the OECD” Journal of Population Economics, Vol. 12-3 pp 431-449.

Maitland, S. B., R. C. Intrieri, K. W. Schaie and S. L. Willis. 2000. "Gender differences and changes in cognitive abilities across the adult life span.", Aging, Neuropsychology, and Cognition, Vol. 7, No. 1, pp. 32-53.

Malmberg, B. and T. Lindh (2002): "Population change and Economic Growth in the Western World, 1850-1990", Paper presented at the $3^{\text {rd }}$ Max Planck Institute on "Demographic Macroeconomic Modeling”, Rostock/Germany, September 2002.

Mark, J. A. 1957. “Comparative Job Performance by Age.”, Monthly Labor Review, No. 80, pp. 1467-1471.

McEvoy, Glenn M. and Wayne F. Cascio 1989. "Cumulative Evidence of the Relationship Between Employee Age and Job Performance.”, Journal of Applied Psychology, Vol. 74, No. 1, pp. 11-17.

Medoff, J. L. and K. G. Abraham 1980. "Experience, Performance, and Earnings.", Quarterly Journal of Economics, Vol. 95, Issue 4.

Medoff, J. L. and K. G. Abraham 1981. "Are Those Paid More Really More Productive? The Case of Experience.", Journal of Human Resources, XVI, No. 2.

Miller, G. F. 1999. "Sexual Selection for Cultural Displays.", in Robin Dunbar, Chris Knight and Camilla Power, eds., The Evolution of Culture, Edinburg University Press, pp. 71-91.

Minois, N. and E. Le Bourg 1997. "Hypergravity and Aging in Drosophila Melonagaster. 9. Conditioned suppression and Habituation of the Proboscis Extension Response", Aging, Experimental and Clinical Research, Vol. 9. No. 4, pp. 1-11. 
Myerson, J., S. Hale, D. Wagstaff, L. W. Ponn and G. A. Smith. 1990. "The Information Loss Model: A Mathematical Theory of Age-Related Slowing.", Psychological Review, Vol. 97, No. 4, pp. 475-486.

Murnane, R. J., J. B. Willett and F. Levy. 1995. "The Growing Importance of Cognitive Skills in Wage Determination.", Review of Economics and Statistics, Vol. LXXVII, No. 2, pp. 251-266.

Murnane, R. J., J. B. Willett, Y. Duhaldeborde and J. H. Tyler. 2000. "How Important are the Cognitive Skills of Teenagers in Predicting Subsequent Earnings?", Journal of Policy Analysis and Management, Vol. 19, No. 4, pp. 547-568.

Nishimura, K. G., K. Minetaki, M. Shirai and F. Kurokawa. 2002. "Effects of Information Technology and Aging Work Force on Labor Demand and Technological Progress in Japanese Industries: 1980-1998" Discussion Paper CIRJE-F-145, Faculty of Economics, University of Tokyo.

OECD 1998. "Work Force Ageing in OECD Countries.", OECD Employment Outlook, Ch. 4 (June), pp. 123-150.

Oster, S. M. and D. S. Hamermesh 1998. "Aging and Productivity Among Economists.", The Review of Economics and Statistics, Vol. 80, No. 1 (Feb), pp. 154-156.

Park, D. C., R. E. Nisbett, and T. Hedden. 1999. "Culture, Cognition, and Aging." Journal of Gerontology, No. 54 B, pp. 75-84.

Remery, C., H., K., Schippers, J. and Ekamper, P. 2003. Managing an aging workforce and a tight labor market: views held by dutch employers. Population Research and Policy Review, Vol. 22, 21-40.

Rodriguez, D. and M. Zavodny 2003. "Changes in the Age and Education Profile of Displaced Workers.", Industrial and Labor Relations Review, Vol. 56. No. 3 (Apr), pp. 498-510.

Rothe, H. F. 1949. "The Relation of Merit Ratings to Length of Service."Personnel Psychology, No. 2 (Summer), pp. 237-242.

Rubin, D. K. and J. M. Perloff 1993 "Who Works for Piece Rates and Why.", American Journal Of Agricultural Economics. No. 627 (Nov), p. 1036-1043.

Rybash, J. M., W. Hoyer and P. A. Roodin. 1986. Adult Cognition and Ageing, New York: Pergamon Press.

Salthouse, T. 1984. "Effects of Age and Skills in Typing.", Journal of Experimental Psychology, No. 113, pp. 345-371.

Salthouse, T. and T. J. Maurer 1996. "Aging, Job Performance and Career Development.", in J. E Birren \& K. W. Schaie eds., Handbook of the Psychology of Aging, 4th ed., Academic Press Inc.

Schaie, K. W. and S. L. Willis 1986a. "Training the Elderly on the Ability Factors of Spatial Orientation and Inductive Reasoning.", Psychology and Aging, Vol. 1, No. 3, pp. 239-247.

Schaie, K. W. and S. L. Willis 1986b. "Can Decline in Intellectual Functioning be Reversed?", Developmental Psychology, Vol. 22, No. 2, pp. 223-232. 
Schaie, K. W. 1994. "The Course of Adult Intellectual Development.", American Psychologist, 49, pp. 304-313.

Schaie, K. W. 1996. Intellectual development in adulthood. The Seattle longitudinal Study. New York. Cambridge University Press.

Schmidt, F. L. and J. E. Hunter 1998. "The Validity and Utility of Selection Methods in Personnel Psychology. Practical and Theoretical Implications of 85 years of Research Findings.”, Psychological Bulletin, Vol. 124, No. 2, pp. 262-274.

Schwartzman, A. E., D. Gold, D. Andres, T. Y. Arbuckle and J Chaikelson. 1987. "Stability of Intelligence. A 40 Year Follow-Up.", Canadian Journal of Psychology, No. 41, pp. 244-256.

Smith, A. D. 1996. "Memory."'in J. E. Birren and K.W. Schaie eds., Handbook of the Psychology of Aging, New York. Academic Press. $4^{\text {th }}$ ed., pp. 236-247 .

Stephan, P. E. and S. G. Levin 1988. "Measures of Scientific Output and the Age-Productivity Relationship.", Ch. 2, in Anthony Van Raan, ed., Handbook of Quantitative Studies of Science and Technology, Elsevier Science Publishers, pp. 31-80.

Tyler, J. H., R. J. Murnane, J. B. Willett. 2000. "Do the Cognitive Skills of School Dropouts Matter in the Labor Market?", Journal of Human Resources, No. 354, pp. 748-754.

U.S. Department of Labor 1957. "Comparative Job Performance by Age. Large Plants in the Men's Footwear and Household Furniture Industries.", Monthly Labor Review, No. 80, pp. 1468-1471.

Verhaegen, P. and T. A. Salthouse 1997. "Meta-Analyses of Age-Cognition Relations in Adulthood. Estimates of Linear and Nonlinear Age Effects and Structural Models.", Psychological Bulletin, Vol. 122, No. 3, pp. 231-249.

Waldman, D. A. and B. J. Avolio 1986. “A Meta-Analysis of Age Differences in Job Performance.”, Journal of Applied Psychology, No. 71, pp. 33-38.

Warr, P. 1994. "Age and Employment", in H. Triandis, M. Dunnette and L. Hough eds.. Handbook of Industrial and Organizational Psychology, $2^{\text {nd }}$ Ed, pp. 485-550, CA. Consulting Psychologist Press.

Willis, S. L. and P. B. Baltes 1980. "Intelligence in Adulthood and Aging: Contemporary issues.", in L. W. Poon ed. Aging in the 1980s, Washington D.C., American Psychological Association, pp. 260-272.

Willis, S. L., and Schaie, K. W. 1998. "Intellectual Functioning in Midlife."; in S. L. Willis \& J. Reid, eds., Life in the middle, San Diego, CA: Academic Press, pp. 233-247. 


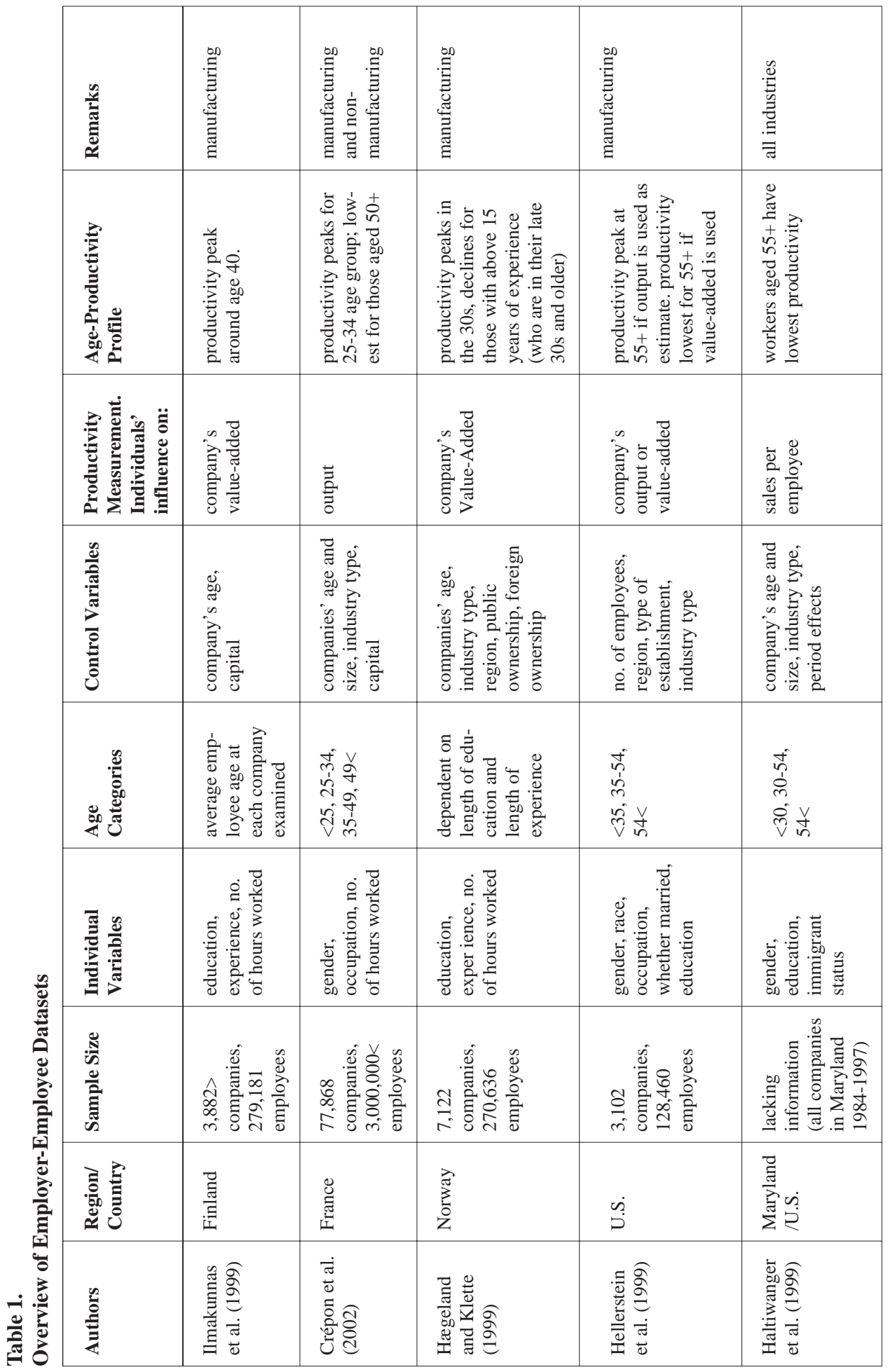




\begin{tabular}{|c|c|}
\hline 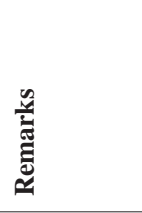 & 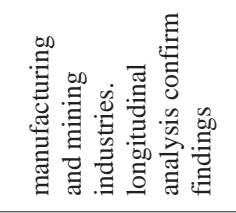 \\
\hline 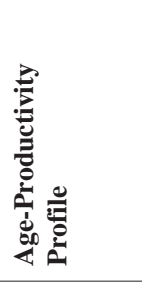 & 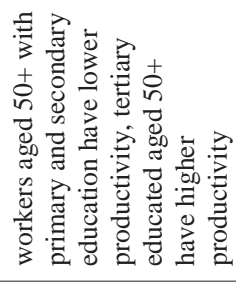 \\
\hline 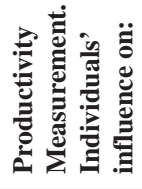 & 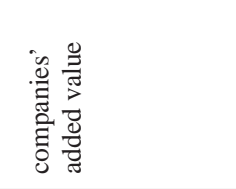 \\
\hline 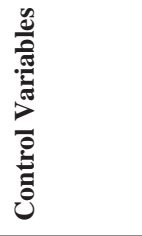 & 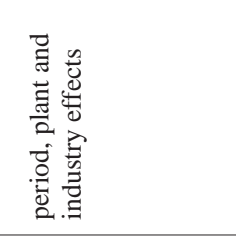 \\
\hline 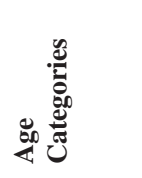 & 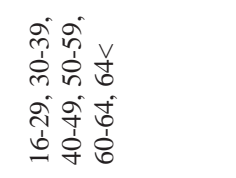 \\
\hline 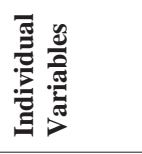 & 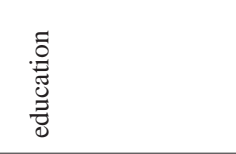 \\
\hline 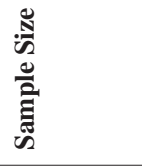 & 芯 \\
\hline 总 & 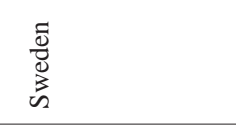 \\
\hline 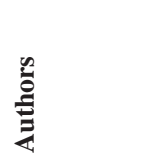 & 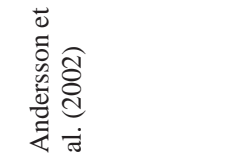 \\
\hline
\end{tabular}


Figure 1:

Outline of Factors Affecting Job Performance

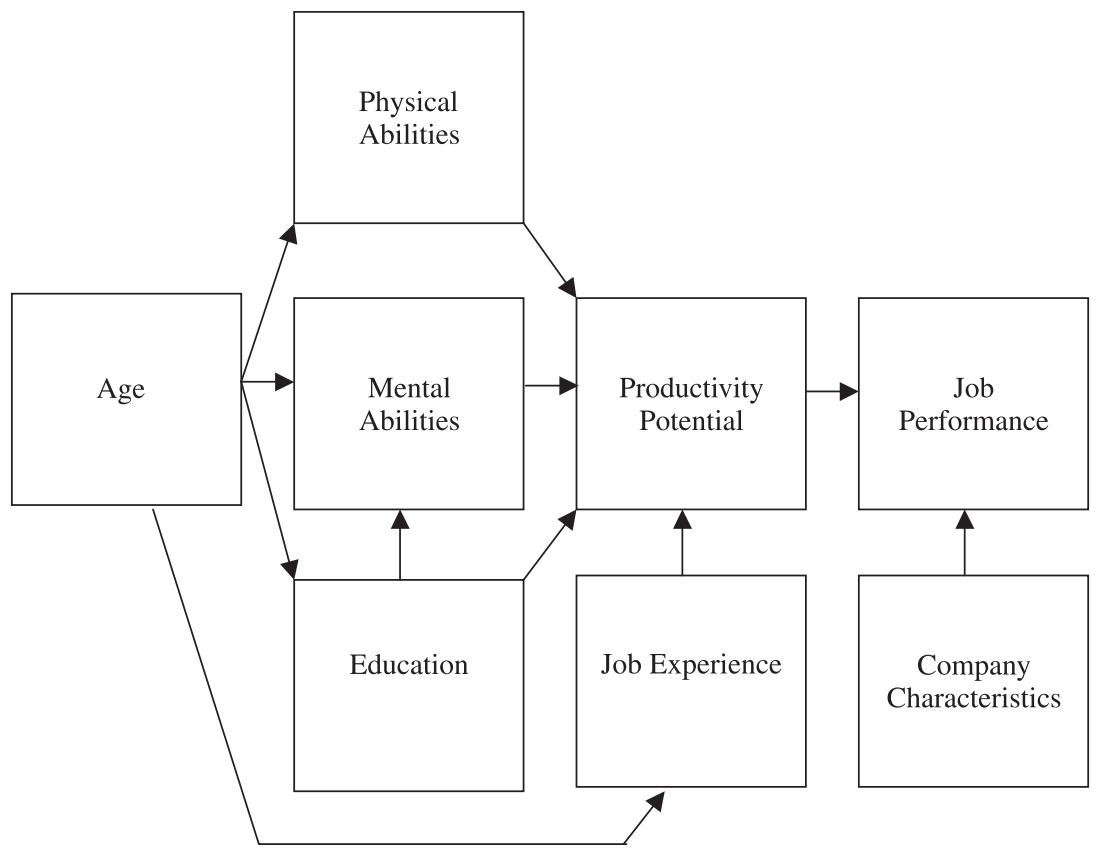

Figure 2:

Ability Levels, Measured in Proportion of 25-34-Year-Old's Standard Deviation. Source: General Aptitude Test Battery (Avolio and Waldman 1994).

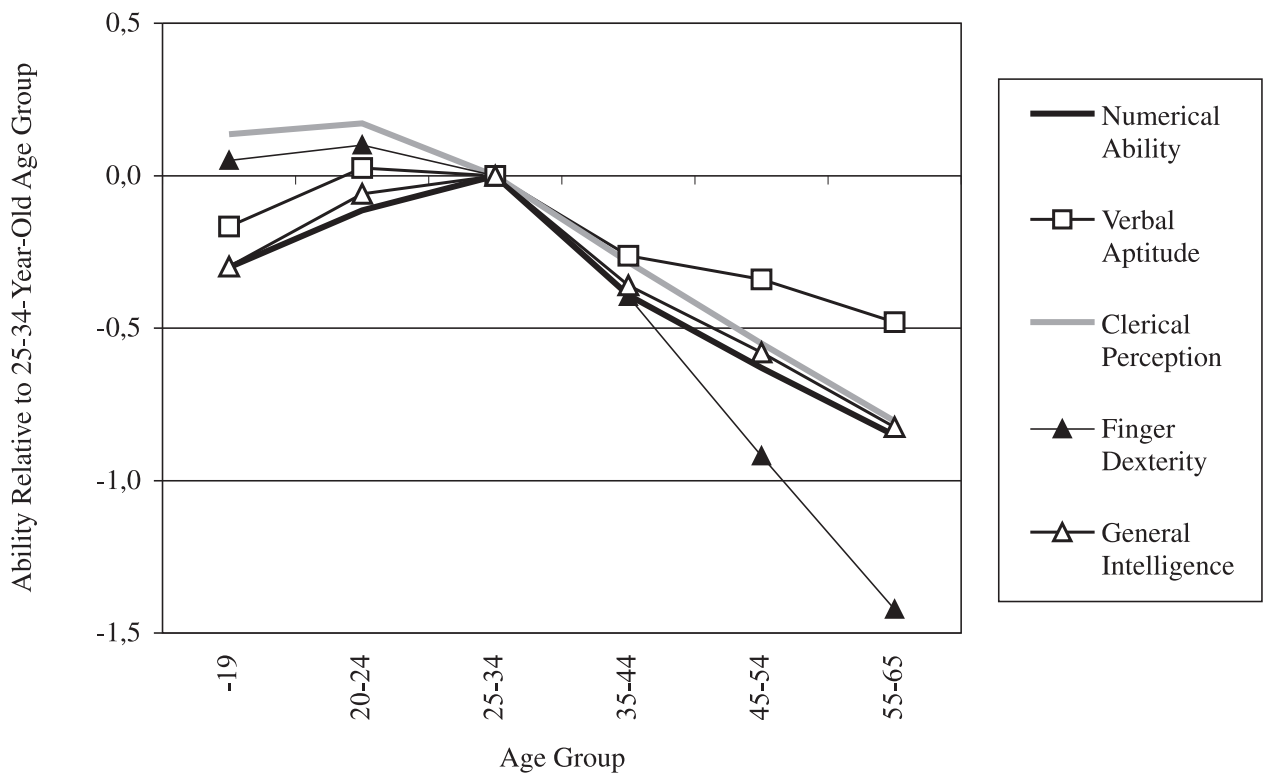


Figure 3:

Stylised Presentation of Productivity and Earnings across the life span.

Based on Lazear (1979) and Jackson (1998).

Wage, Marginal Productivity

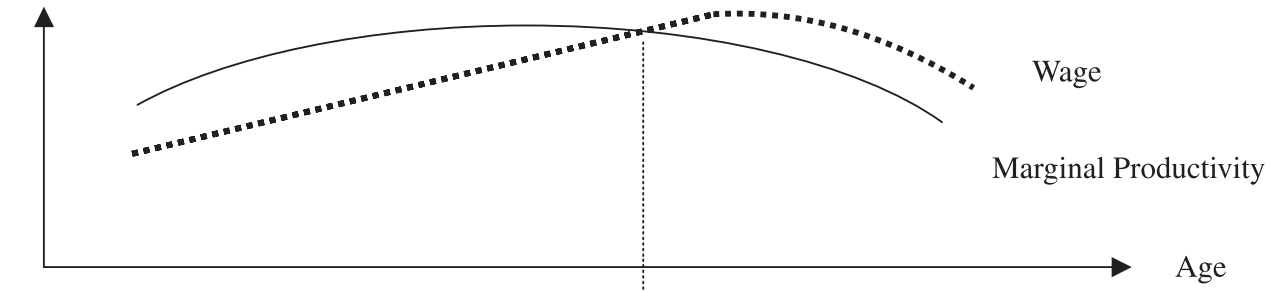

Productivity - Wage

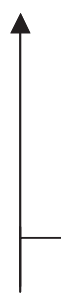

Distribution of Workers, by Age

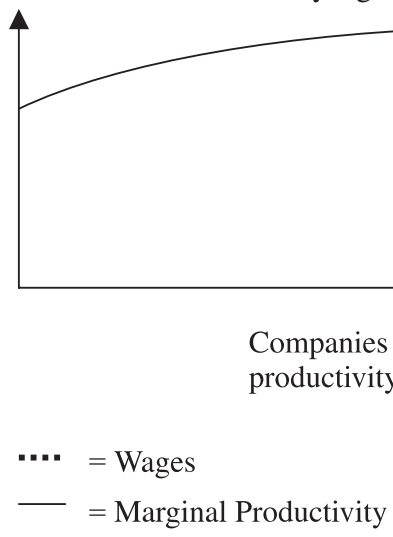

Age

Companies lose by wage-

productivity gap

Age

Companies gain by wageproductivity gap

Age

. 
